\title{
Children's and parents' views about using mobile phones to support outdoor play
}

\author{
Karen Moyse
}

\author{
Citation \\ Moyse K (2019) Children's \\ and parents' views about \\ using mobile phones to \\ support outdoor play. Nursing \\ Children and Young People. \\ doi: 10.7748/ncyp.2019.e1026
}

\section{Peer review}

This article has been subject to open peer review and has been checked for plagiarism using automated software

\section{Correspondence}

Bazbuster7@gmail.com

\section{Conflict of interest}

None declared

\section{Accepted}

19 July 2018

\section{Published}

May 2019

\section{Open access}

This is an open access article distributed under the terms of the Creative Commons Attribution-Non Commercial 4.0 International (CC BY-NC 4.0) licence (see https:// creativecommons.org/licenses/ by-nc/4.0/), which permits others to copy and redistribute in any medium or format, remix, transform and build on this work non-commercially, provided appropriate credit is given and any changes made indicated

\section{Permission}

To reuse this article or for information about reprints and permissions, please contact permissions@rcni.com

\begin{abstract}
Background The mobile phone is significant in the lives of UK middle-school children aged 7-I2 years. Drawing on a study about children and mobile phones, this article compares children's outdoor play behaviours with those from the past.

Aim To explore the views of children and parents about children's use of mobile phones and provide children with a voice in the research.

Method Qualitative focus groups and interviews were used to explore participants' views. A thematic analysis was applied to the data collected.

Findings In understanding children's play behaviours involving mobile phones, parents made comparisons with their own childhoods during the 1970s and 1980s. Parents were concerned about their children engaging in outdoor play but they thought the use of mobile phones could help keep children safe.
\end{abstract}

Conclusion Nurses could promote mobile-supported outdoor play through health promotion activities, helping children to develop some freedoms.

\section{Author details}

Karen Moyse, chartered psychologist and children's nurse, Harmony Tree International, Repulse Bay, Hong Kong, China

\section{Keywords}

child behaviour, child health, health promotion, parents, professional issues, technology

\section{Background}

The mobile phone is an important device in the lives of UK middle-school children aged 7-12 years. They enjoy communicating with friends using their mobiles (Haddon and Vincent 2014, 2015). There are concerns that children are not active enough (Department of Health (DH) 2016) and that use of mobiles and similar devices could be discouraging children from being as healthy as they could be (Kremer and Williams 2014).

This article compares children's play behaviours today with their play behaviours in the 1970s and 1980s. It draws on a recent study that explored children's use of mobile phones, focusing on one aspect of it - children's outdoor play (Moyse 2016). The 1970s and 1980s were selected as a comparison period because many of the parents who participated in the study were children themselves during this time and so could relate to their own childhood experiences.

The rationale behind the study was the researcher's interest in observing how children aged 7-12 years were increasingly using mobiles.
By 2010 mobiles had been popular with young people for some time. However, use of mobiles was a new behaviour for children aged 7-12 years. Further, it was happening within a social context of increased interest in mobile use among adults, particularly with the emergence of smartphones (Chatfield 2011).

At the time there was minimal research on this topic in the UK that focused on children aged 7-12 years. The author undertook a study (Moyse 2016) to explore children's and parents' views on children's use of mobile phones and to develop an understanding about children's social behaviours. Researchers felt that children's interactions with mobiles were likely to increase in the future (Haddon 2007).

\section{Literature review}

Children aged 7-12 years are neither as dependent as their younger counterparts, nor are they striving for independence in the way that young people do. Parents are involved with their children's lives at this stage (Collins et al 2012). Children enjoy 
being sociable with their friends (Collins et al 2012) and their communication skills are well developed (Cornoldi 2014). They are usually active (Collins et al 2012) but encouraging children to engage in daily physical activity has become increasingly important in recent years for the benefit of their health (DH 2016).

Play is significant because it helps children to understand their social worlds (Smith et al 2015). Children want to explore their local environments, socially and behaviourally, through outdoor play: riding bikes, going to the local shops, visiting playgrounds and parks with friends, all interest them. Play England (2019a) advocates that children should have the freedom to play outside independently in this way, close to where they live. However, for a variety of reasons this is not always possible.

Studies on outdoor play demonstrate how it was once part of children's lives but has declined in recent times (Pooley 2011). In the past children could regularly be seen playing outdoors in their local communities (Gray 2011). Outdoor play was perceived as a relatively safe activity (Pooley 2011). This was particularly so in the 1970s and 1980s compared to subsequent decades, with children regularly engaging in a variety of outdoor play activities (Frost 2010). From the 1990s onwards, however, parents became increasingly worried about children playing outdoors (Borland et al 1998). Parents felt the need to keep children safe at home because they were concerned about increased traffic levels and 'stranger danger' (Borland et al 1998).

Children enjoy the different activities they can engage in using their mobiles (Vincent 2015). The UK's communications regulator Ofcom, which produces yearly reports on children's use of different social media, has found an increase in their use of mobiles. Figures for 5-15 year olds show that $68 \%$ of this age group were using mobiles in 2017, compared with $62 \%$ in 2016 (Ofcom 2017). Among 8-11 year olds there was an increase in smartphone ownership from $32 \%$ in 2016 to $39 \%$ in 2017.

Research by Leslie Haddon (Haddon and Vincent 2014, 2015, Vincent 2015), a leading figure in children's and young people's use of social media, found that mobiles could have a positive and negative influence on children's behaviours. Dr Haddon was concerned that some children's use of mobiles could lead to isolated play behaviours, resulting in excessive time spent in their bedrooms interacting on mobiles. However, mobiles can have a role beyond the home for children, which may not necessarily influence isolating behaviours but encourage more outgoing ones.
Outdoor play is a normal part of childhood. A decline in outdoor play could have a negative effect on children's health (Frost 2010). Children have been criticised for their lack of participation in outdoor play, with some sources suggesting that this is due to their interest in mobile phones. The Telegraph (2015), for example, reported that children were spending too much time on their mobile devices and not enough engaged in physical activities such as playing out with friends. Frost (2010) maintains that parents are worried about children's safety. Parents fear that outdoor play exposes their children to risks (Valentine and McKendrick 1997). In some situations parents' concerns might lead to a restriction of children's outdoor play opportunities (Frost 2010), rather than supporting them.

Children may be interested in mobile phones because other forms of play are now off limits. Parents' concerns about outdoor play could be limiting children's activities and social contacts. Studies have found that using mobiles is a way for children to maintain contact with their friends when they are not with them (Boyd 2014, Haddon and Vincent 2014, 2015). A decline in children's outdoor play might be a result of parents' concerns rather than children's lack of interest. Mobiles could perhaps help to increase outdoor play opportunities, fostering children's social contacts and physical activities, which the study explores.

\section{Aims}

The aims of the study were to:

" Develop knowledge about use of mobile phones among children aged 7-12 years. ॥ Provide children with a voice in the research. Alderson and Morrow (2011) maintain that children are often not given the opportunity to participate in research which is about them. The researcher felt it was important to provide children with a voice on matters that concerned them, namely mobile phones.

The research questions were:

»What do mobile phones mean to children aged 7-12 years?

"What are parents' views about their children's use of mobile phones?

Children's and parents' views were explored. As this was a new area of research there was no set focus and participants' views determined the focus. The research questions were broad enough to allow participants' views to develop and key themes to emerge.

Maxwell's (2012) critical reality, the epistemological approach applied to the

\section{Implications for practice}

- Advice for parents about mobile-supported outdoor play:

- Discuss outdoor play opportunities and benefits

- Identify where is safe to play

- Children should inform parents of their whereabouts and activities

- Agree contact times

- Jointly agree strategy for outdoor play

- Group health promotion activities:

- Children's awareness and safe navigation of the streets

- Road safety

- Safe use of mobile phones

- Nurses should keep up to date with relevant literature 
study, enables knowledge (theories on child development) and participants' experiences of reality to be appreciated equally in a qualitative research context. This provided a flexible but informed basis on which to construct the study. Bronfenbrenner's (1979) theory on social relationship settings provided a foundation for knowledge development. Children's views about their mobile phone use were likely to show different social settings, with different relationships within those settings being demonstrated. By applying Bronfenbrenner's (1979) theory this would help to develop an understanding about children's social behaviours within those settings.

\section{Method}

Design

A triangulated research design (Denzin 2012) was applied, triangulating the views of different participants with theories. Adopting critical realism (Maxwell 2012), with its qualitative approach aimed to help participants, especially children, express their views easily. Quantitative approaches would have imposed limits due to the set formats of research tools (Parahoo 2006, Bryman 2012), which would have been too restrictive for exploring children's views in this research context.

\section{Participants and methods}

Purposive sampling was used for data collection (Burns and Grove 2011). A sample of 30 parents and 30 children from the Midlands participated. Participants were recruited from a local school in response to information leaflets circulated about the study. The inclusion criterion for parents was that they had to be the parent of a middle school-aged child. Criteria for children were that they needed to be of middle school age (7-12 years) and have some interest in mobiles. At the time researching this age group was important because these children represented some of the first of their generation to be using mobile phones. The sample could therefore provide important insights into children's social behaviours.

The ages 7-12 years were chosen as the cut-off points for the sample because those younger than seven years were largely not using mobile phones and those older than 12 years had more experience of using mobiles. Children and parents were invited to talk freely in focus groups and interviews (Krueger and Casey 2009, Kvale and Brinkmann 2009).

Data collection and analysis

Data collection involved four focus groups with parents, three children's focus groups and 11 children's interviews. After each focus group and interview, data analysis took place, which was insightful as the themes identified in one situation could be further researched in the next, to gain greater understanding. Thematic analysis (Braun and Clarke 2013) was applied to the data for identification of key themes.

\section{Ethical considerations}

The University of Lincoln's School of Psychology ethics committee approved the research. The British Psychological Society's (2014) Code of Human Research Ethics was consulted, particularly on children's role in research. Fulfilling the ethical duty of confidentiality, for example, children's data were handled in a trustworthy way. The information they provided was anonymous; to protect their identities no real names or locations were identified. Pseudonyms were used throughout. To fulfil the duty of justice (fairness), care was taken to encourage children to share their ideas and simple explanations were provided on why their ideas were important to the research.

\section{Findings and discussion}

Risks and opportunities were identified as themes but rejected as they provided no new understanding on what was unique about children and mobiles. Safety was another theme identified, particularly in parents' data. This theme was put aside because, although it was evident in children's data, it was not their strongest theme.

Freedom was a strong theme in children's data, shown through socialising with friends and thoughts about outdoor play. Parents had an important role in supporting children's freedom by keeping them safe.

\section{Freedom}

Children enjoyed the freedom associated with outdoor play, but with their mobiles. One said:

'I always take my phone' (Janie, 12).

Mobiles enabled children to participate in outdoor play safely as they were able to contact their parents if there was a problem. European studies have found similar evidence that mobiles support safe independent behaviours in children and young people (Oksman and Turtiainen 2004, Geser 2006).

In parents' discussions outdoor play emerged, particularly when they were trying to understand children's play behaviours. Parents remembered their own play experiences as children in the 1970s and 1980s:

'I could go anywhere, I just played out in the streets' (Parent 1). 
'I used to get on my bike and I would be gone all day' (Parent 2).

While parents reflected positively they felt children's experiences today were risky in comparison because of busy streets and 'busy people':

'They are all in a rush. It is all these busy people' (Parent 3).

The type of people children might encounter on the streets was thought to be a risk:

'They need to suspect people when out' (Parent 4).

Discussing their concerns and reflecting on childhood memories helped parents to understand children's desire for outdoor play. To overcome their concerns parents sometimes allowed their children to play out, but always with a mobile phone:

'She takes her phone' (Parent 5).

Parents needed the mobile so they could regularly connect with their children, checking they were safe. Similar evidence has been found in studies of young people and their parents; young people were given mobiles to help keep them safe (Ling and Helmersen 2000, Boyd 2014).

Children who played outdoors always used their mobiles. They usually contacted their parents to let them know where they were and what they were doing. If children experienced difficulties, they contacted home:

'Like, if I am in town and I have missed a bus, then I would phone my mum to come and pick me up' (Janie, 12).

'You are in trouble... get your phone' (Jack, nine).

Children felt safer with the mobile, similar to young people.

'Mmm, I like the fact when I go out I have got my phone and know if anything was wrong I could contact home (Rebecca, 14).

Parents checked their children's whereabouts regularly:

'So, I will pop him a call - where are you?' (Parent 6).

Parents used the mobile as a resource for parenting:

'If he needs anything he can just phone.

Then I know that he is safe' (Parent 7).

The mobile reassured children and parents.

It was a resource that provided children with opportunities:

'The mobile is enabling him to do more. It is allowing him to have more freedom' (Parent 8).

Without mobiles children might not have been able to have the freedom to play out. Parents were preparing their children for outdoor play, including how to handle any risks they might encounter.
These findings show that children were participating in outdoor play, but only with the proviso of the mobile. Parents expressed similar concerns to those discussed by Borland et al (1998). Being able to contact their children by mobile eased parents' concerns. Ribak (2009) also found that use of mobiles maintained close connections between young people and their parents.

The mobile seemed to support children with positive play experiences for health and development, rather than negative ones, as some maintain (Bianchi and Phillips 2005, Haddon and Vincent 2015). Children were able to develop some freedoms, contrary to what other evidence might suggest.

Parents' childhoods of the 1970s and 1980s may often be reflected on as safe and secure times, where children enjoyed playing out with their friends without experiencing difficulties. However, accounts have emerged in recent years showing that the 1970s and 1980s were not always safe - for example the systematic abuse of children by TV personality Jimmy Savile (BBC Trust 2016) - as evidence from this study also suggests.

One parent reported that as a 12-yearold she was playing out with her friend and experienced a problem. She recounted a story about how her friend's father started to make inappropriate comments to her. It was only later when she returned home and thought about the incident that she realised how serious it was. This was an unusual story, as most parents' memories about the past were positive. Parents may have been trying to make sense of the present based on what the past represented to them.

Written accounts of children engaging in outdoor play in the past often do not reflect apprehension (Pooley 2011), as children might express today. However, parents in the research seemed to have found a way of managing their concerns about children's outdoor play. The number of children participating in outdoor play has declined (Children's Commissioner 2018a). Figures from Play England (2019b) show that, while $71 \%$ of adults played in the street or area near their home every day when they were a child, only $21 \%$ of children do so now.

Parents' concerns may be contributing towards this decline. However, parents in this study seemed to have found a way of managing their concerns. By providing children with a mobile phone they could experience freedom to communicate socially and engage behaviourally with others, a normal part of child development (Erikson 1963). NURSING CHILDREN
\& YOUNG PEOPLE RESOURCES

How to encourage children to use mobile phones safely (20II) rcni.com/phone-safety

A nurse's role in promoting social capital in children and young people (2013) rcni.com/social-capital

How young people can learn about newly diagnosed type I diabetes (2016)

rcni.com/young-diabetes 
Concern has been expressed (Haddon and Vincent 2014, 2015) that mobiles can lead children towards more isolating play behaviours. However, the findings from this study suggest that mobiles can support children's freedom, helping them to engage in play opportunities with friends beyond their own homes. This study has shown that children having a mobile phone does not necessarily lead to negative behaviours as some maintain. Mobiles can help support positive behaviours.

\section{Limitations}

The findings relate to the children and parents who participated in the study. Parents were supportive of their children's need for freedom created through outdoor play. However, a different sample of parents might be less supportive of children's need for freedom and therefore the findings could be different. Further research should be undertaken to obtain wider knowledge (Bryman 2012).

\section{Advice for nurses}

Children can benefit physically and mentally from playing outdoors. For example, the charity Play England (2019c) highlights that parks and open spaces enable children to engage in play such as ball games and to explore nature. The government's childhood obesity strategy (DH 2016) states that one third of children aged 2-15 years are overweight or obese. Outdoor play encourages children to participate in regular exercise, helping to prevent weight gain. Further, it gives children the freedom to stay mentally well (Mental Health Foundation 2019). Outdoor play offers children the opportunity to get to know their local community with the potential to develop new friendships. Not all children go to local schools now and therefore they might not be aware of the opportunities for friendship that exist nearby. Forming new friendships can help children feel connected to others (Boyd 2014). With outdoor play this happens in person, not through a mobile device.

Nurses can advise parents about children participating in mobile-supported outdoor play, for example, by encouraging parents to discuss with their children safe areas to play, areas to avoid, where they are, who they are with and when to contact home. Joint discussions between parents and children enable an agreed strategy to be adopted. Mascheroni (2014) emphasises that jointly agreed strategies about mobile use are more likely to be effective with children. Nurses could undertake group health promotion activities with children and parents together, providing this practical advice. Activities could be linked, for example, with Child Safety Week (Child Accident Prevention Trust 2018), which aims to raise awareness of the risks of child accidents, could be made fun and interesting.

Nurses also need to keep up to date with relevant literature. UK literature sources can be found by consulting studies from the Net Children Go Mobile project (Livingstone et al 2014, Vincent 2015). Consultation and policy documents are also useful. For example, publications by the Children's Commissioner, such as Growing Up Digital (Children's Commissioner 2017), discuss rapid technology change and how children's rights are being realised and infringed. Life in 'Likes' is another report by the Children's Commissioner (2018b) exploring social media use among 8-12 year olds.

Box 1 summarises how nurses can discuss mobile-supported outdoor play with parents. Further information can be found in an article by Moyse (2011).

This article has illustrated how evidence from children's past can be meaningful in understanding their behaviours today. Outdoor play may be riskier for some children compared with their parents' generation, but access to a mobile phone can help children connect with home and enjoy some freedom. In this sense, mobile phones can have a positive influence on their lives, acting as a resource to support freedom.

\section{Conclusion}

This study has provided important insights into children's social behaviours, demonstrating how mobiles can have a positive influence on those behaviours. Research questions about the meaning of mobile phones to children, along with parents' views, were explored and have been presented.

\section{Box I. Facilitating outdoor play}

Advice for parents about mobile-supported outdoor play:

॥ Discuss outdoor play opportunities and benefits

I Identify where is safe to play

॥ Children should inform parents of their whereabouts and activities

》) Agree contact times

॥ Jointly agree strategy for outdoor play

Group health promotion activities:

॥ Children's awareness and safe navigation of the streets

॥ Road safety

॥ Safe use of mobile phones

I Nurses should keep up to date with relevant literature 
This generation of middle school children wanted their freedoms supported by the mobile phone. Outdoor play emerged as the most important social context for freedom.

Parents' views showed concerns about outdoor play, but children having access to a mobile helped alleviate those concerns. The mobile was therefore an essential resource for parenting which enabled children and parents to remain closely connected.

An important research aim was to explore children's views and this was achieved by giving them a voice in the research. The research methods used helped to facilitate this by adopting an informal approach, so that children felt confident to share their views. The methodology, critical realism (Maxwell 2012), enabled children's and parents' views to be considered important. Bronfenbrenner's (1979) theory illustrated that the parent-child setting was fundamentally important for children's mobile communications at this stage of development (7-12 years).

Recommendations for nursing practice can be made. Nurses can help promote mobile-supported outdoor play, so that children's health might benefit, just as children experienced in the past. Children can use mobiles to support their social and behavioural freedoms (Moyse 2015, 2016).

\section{References}

Alderson P, Morrow V (2011) The Ethics of Research with Children and Young People. A Practical Handbook. Sage Publications, London.

BBC Trust (2016) The Dame Janet Smith Review Report - An Independent Review into the BBC's Culture and Practices During the Jimmy Savile and Stuart Hall Years. BBC Trust, London.

Bianchi A, Phillips I (2005) Psychological predictors of problem mobile phone use. Cyberpsychology \& Behavior. 8, 1,39-51

Borland M, Laybourn A, Hill M et al (1998) Middle Childhood. The Perspectives of Children and Parents. Jessica Kingsley, London.

Boyd D (2014) It's Complicated, the Social Lives of Networked Teens. Yale University Press, New Haven CT and London.

Braun V, Clarke V (2013) Successful Qualitative Research. A Practical Guide for Beginners. Sage Publications, London

British Psychological Society (2014) Code of Human Research Ethics. Second edition. BPS, Leicester.

Bronfenbrenner U (1979) The Ecology of Human Development: Experiments by Nature and Design Harvard University Press, Cambridge MA.

Bryman A (2012) Social Research Methods. Fourth edition. Oxford University Press, Oxford.

Burns N, Grove S (2011) Understanding Nursing Research: Building an Evidence-based Practice. Fifth edition. Elsevier Saunders, Maryland Heights MO.

Chatfield T (2011) 50 Digital Ideas You Really Need to Know. Quercus, London.

Child Accident Prevention Trust (2018) Child Safety Week 2018. www.childsafetyweek.org.uk (Last accessed: 8 April 2019.)

Children's Commissioner (2017) Growing Up Digital. A Report of the Growing Up Digital Taskforce. Children's Commissioner for England, London.

Children's Commissioner (2018a) Playing Out. A Children's Commissioner for England Report Looking at the Importance to Children of Play and Physical Activity. Children's Commissioner for England, London.
Children's Commissioner (2018b) Life in 'Likes': Children's Commissioner Report into Social Media Use Among 8-12 Year Olds. Children's Commissione for England, London.

Collins W, Madsen S, Susman-Stillman A (2012) Parenting during middle childhood. In Bornstein M (Ed) Handbook of Parenting Volume 1: Children and Parenting. Second edition. Lawrence Erlbaum Associates, Mahwah NJ, 73-102

Cornoldi C (2014) Origins of intentional strategic memory in the child. In Inhelder B, de Caprona, Wells A (Eds) Piaget Today. Psychology Press, Hove, 183-202.

Denzin N (2012) Triangulation 2.0. Journal of Mixed Methods Research. 6, 2, 80-88.

Department of Health (2016) Childhood Obesity: A Plan for Action. DH, London.

Erikson E (1963) Childhood and Society. Second edition. Norton, New York NY.

Frost J (2010) A History of Children's Play and Play Environments: Toward a Contemporary ChildSaving Movement. Routledge, Abingdon.

Geser H (2006) Pre-teen cell phone adoption: consequences for later patterns of phone usage and involvement. Sociology in Switzerland: Sociology of the Mobile Phone. socio.ch/mobile/t_ geser2.htm (Last accessed: 20 March 2019.)

Gray $P(2011)$ The decline of play and the rise of psychopathology in children and adolescents. American Journal of Play. 3, 4, 443-463.

Haddon L (2007) Looking for diversity: children and mobile phones. In Goggin G, Hjorth L (Eds) Proceedings of the Conference Mobile Media 2007. Department of Media and Communications, University of Sydney, Australia, 2-4 July, 97-106.

Haddon L, Vincent J (Eds) (2014) European Children and their Carers' Understanding of Use, Risks and Safety Issues Relating to Convergent Mobile Media. Report D4.1. Unicatt, Milano.

Haddon L, Vincent J (2015) UK Children's Experiences of Smartphones and Tablets: Perspectives from Children, Parents and Teachers. London School of Economics and Political Science Net Children Go Mobile, London.
Kremer P, Williams J (2014) Physical activity, leisuretime screen use and depression among children and young adolescents. Journal of Science and Medicine in Sport. 17, 2, 183-187.

Krueger R, Casey M (2009) Focus Groups: A Practical Guide for Applied Research. Fourth edition. Sage Publications, Thousand Oaks CA.

Kvale S, Brinkmann S (2009) InterViews: Learning the Craft of Qualitative Research Interviewing. Second edition. Sage Publications, Thousand Oaks CA.

Ling R, Helmersen P (2000) 'It must be necessary, it has to cover a need': the adoption of mobile telephony among pre-adolescents and adolescents. Paper presented at The Social Consequences of Mobile Telephony Conference, 0slo, 16 June.

Livingstone S, Haddon L, Vincent J et al (2014) Net Children Go Mobile: The UK Report. London School of Economics and Political Science, London.

Mascheroni G (2014) Parenting the mobile internet in Italian households: parents' and children's discourses. Journal of Children and Media. 8, 4, 440-456.

Maxwell J (2012) A Realist Approach for Qualitative Research. Sage Publications, Thousand Oaks CA.

Mental Health Foundation (2019) Children and Young People. www.mentalhealth.org.uk/a-to-z/c/childrenand-young-people (Last accessed: 8 April 2019.)

Moyse K (2011) How to encourage children to use mobile phones safely. Nursing Children and Young People. 23, 10, 24-26

Moyse K (2015) Behavioural and Social Freedoms for Children Via Mobile Phones and Internet Devices. Paper presented at Investing in Futures Conference, British Psychological Society, Birmingham, 6-7 0ctober

Moyse K (2016) Developing Freedom: Behavioural and Social Freedoms for Children via Mobile Phones and Internet Devices. PhD thesis. University of Lincoln, Lincoln.

Ofcom (2017) Children and Parents: Media Use and Attitudes Report. Ofcom, London.

Oksman V, Turtiainen J (2004) Mobile communication as a social stage: meanings of mobile communication in everyday life among teenagers in Finland. New Media \& Society. 6, 3, 319-339.

Parahoo K (2006) Nursing Research, Principles, Process and Issues. Second edition. Palgrave Macmillan, Basingstoke.

Play England (2019a) About Us. www.playengland. org.uk/about-us (Last accessed: 8 April 2019.)

Play England (2019b) Streets. www.playengland. org.uk/streets (Last accessed: 8 April 2019.)

Play England (2019c) Parks and Open Spaces www.playengland.org.uk/parks-and-open-spaces (Last accessed: 8 April 2019.)

Pooley C (2011) Young people, mobility and the environment: an integrative approach. In Grieco M, Urry J (Eds) Mobilities: New Perspectives on Transport and Society. Ashgate Publishing, Farnham, 271-288

Pooley C (2011) Young people, mobility and the environment: an integrative approach. In Grieco M, Urry J (Eds) Mobilities: New Perspectives on Transport and Society, Ashgate Publishing, Farnham, 271-288

Ribak R (2009) Remote control, umbilical cord and beyond: the mobile phone as a transitional object. British Journal of Developmental Psychology. 27, Pt 1, 183-196.

Smith et al (2015) (Eds) Understanding Children's Development. Sixth edition. John Wiley \& Sons, Chichester

Telegraph (2015) Parents: children spend too much time playing with gadgets on holiday. www.telegraph.co.uk/technology/mobilephones/11511337/Parents-children-spend-toomuch-time-playing-with-gadgets-on-holiday.html (Last accessed: 8 April 2019.)

Valentine G, McKendrick J (1997) Children's outdoor play: exploring parental concerns about children's safety and the changing nature of childhood. Geoforum. 28, 2, 219-235.

Vincent J (2015) Mobile Opportunities. Exploring Positive Mobile Media Opportunities for European Children. London School of Economics and Political Science, POLIS, London. 